\title{
Original Paper / Artigo Original New registers of colleters in species of Myrtaceae from Brazilian Cerrado
}

\author{
Cleber José da Silva ${ }^{1,3}$, João Paulo Oliveira Ribeiro ${ }^{1}$ \& Renata Maria Strozi Alves Meira ${ }^{2}$
}

\begin{abstract}
Colleters are secretory structures that produce a sticky substance, consisting of a mixture of mucilage, proteins, terpenes, pectic substances and even alkaloids, which lubricates and protects the shoot apical meristem. Several colleter types have been described and have taxonomic value in many botanical families. In Myrtaceae, the colleters description is recent and presents three new morphological types (conic, euryform and petaloid) that differ those already described for other eudicots. In this work, we report the colleters morphological types in six species of three genera belonging to the Myrteae tribe of Myrtoideae from the Brazilian Cerrado. The samples were fixed for light and scanning electron microscopy. Histochemical tests were carried out on the fresh and methacrylate-embedded material. The conic and euryform colleters from Myrtoideae species of the Cerrado did not differ either morphologically nor as to the secretion nature from those described for Myrtoideae species from others biomes, which may indicate their potential use for taxonomic purposes. Considering the hypothesis that the multiple fleshy-fruit lineages have evolved independently in Myrteae tribe, our results indicate the relevance of additional studies in order to recognize the pattern of distribution of colleters in Myrtaceae.
\end{abstract}

Key words: histochemistry, mucilage, Myrtoideae, secretory structure, vegetative meristems.

\begin{abstract}
Resumo
Coléteres são estruturas secretoras que produzem uma substância pegajosa, constituída por uma mistura de mucilagens, proteínas, terpenos, substâncias pécticas e até alcaloides, que lubrifica e protege o meristema apical. Vários tipos de coléteres têm sido descritos e apresentam valor taxonômico em muitas famílias botânicas. Em Myrtaceae, a descrição de coléteres é recente apresentando três novos tipos morfológicos (cônico, euriforme e petalóide) que diferem dos já descritos para outras eudicotiledôneas. Neste trabalho, são descritos os tipos morfológicos de coléteres em seis espécies de três gêneros pertencentes à tribo Myrteae da subfamília Myrtoideae do Cerrado brasileiro. As amostras foram fixadas para microscopia de luz e eletrônica de varredura. Testes histoquímicos foram realizados em material fresco e em incluído em metacrilato. Foram observados coléteres cônico e euriforme, que não diferiram nem morfoanatomicamente nem quanto à natureza de secreção, daqueles já descritos para espécies de Myrtoideae, o que pode indicar seu uso potencial para fins taxonômicos. Considerando a hipótese de que as linhagens múltiplas de frutos carnosos evoluíram de forma independente na tribo Myrteae, nossos resultados indicam a relevância de estudos adicionais para se reconhecer o padrão de distribuição de coléteres em Myrtaceae.
\end{abstract}

Palavras-chave: histoquímica, mucilagem, Myrtoideae, estrutura secretora, meristemas vegetativos.

\section{Introduction}

The plant's vegetative shoot apex is essential to ensure their growth. They are composed of meristematic tissues (Fahn 1979). These tissues are thin and susceptible to desiccation due to environmental factors such as wind and solar radiation, which are more intense in the Cerrado (Brazilian Savanna), where the dry period is prolonged and the plants resume their growth after winter dormancy (Sano et al. 2008). In this context, the colleters are an important secretory structure that protects the shoot apex.

\footnotetext{
${ }^{1}$ Universidade Federal de São João Del-Rei, campus Sete Lagoas, R. Sétimo Moreira Martins 188, 35702-031, Sete Lagoas, MG, Brazil.

${ }^{2}$ Universidade Federal de Viçosa, Av. PH Rolfs s/n, 36570-900, Viçosa, MG, Brazil.

${ }^{3}$ Author for correspondence: cleberjs@ufsj.edu.br
} 
The term colleter comes from the Greek colla and refers to the secretion produced by the colleters, which occur in the vegetative shoot apex of many plant species and in young foliar organs, or on the adaxial face of stipules, petioles, bracts, calyx and corolla (Thomas 1991). The colleter's sticky secretion is a mixture of mucilage, proteins, terpenes, pectic substances and even alkaloids, which lubricates and protects the shoot apical meristem (Fahn 1979; Mayer et al. 2013).

Colleters are widely distributed on young vegetative and reproductive organs in plants and have been reported in ferns (Oliveira et al. 2017), monocots (Leitão \& Cortelazzo 2008; Mayer et al. 2011; Cardoso-Gustavson et al. 2014) and in sixty-five eudicots families (Thomas 1991; Muravnik et al. 2014) such as Apocynaceae, Gentianaceae, Rubiaceae, (Thomas 1991; Renobales et al. 2001; APG 2009; Lopes-Mattos et al. 2015; Tresmondi et al. 2015). Anacardiaceae (Lacchia et al. 2016), Aquifoliaceae (González \& Tarragó 2009), Euphorbiaceae (Machado et al. 2015; Vitarelli et al. 2015), Fabaceae (Barros \& Teixeira 2016), Lecythidaceae (Paiva 2012), Moraceae (Machado et al. 2013), Rutaceae (Macêdo et al. 2016), Rhizophoraceae (Sheue et al. 2012) and Myrtaceae (Silva et al. 2012).

In Myrtaceae, the colleters present three morphological types that differ those already described for other eudicots: (1) the petaloid type, with an axis that is flattened dorsiventrally, being much wider than thick and short; (2) the conic type has an axis, observed in the cross-section as a circular or ellipsoid form, with a decreasing diameter towards the apex and (3) the euryform type that is flattened dorsiventrally, but has an axis that is much wider than thick and longer than wide (Silva et al. 2012).

Myrtaceae is the largest family of Myrtales and there are about 140 genera and more than 3.000 species (Johnson \& Briggs 1984; Wilson et al. 2001; Moura \& Franzener 2015). In Brazil, Myrtaceae is one of the ten richest angiosperm families and is also considered one of the ten main Cerrado families in the number of genera (14) and species (211) (Mendonça et al. 1998).

Myrtaceae is divided into two subfamilies: Myrtoideae (with 15 tribes) and Psiloxyloideae (with two tribes: Psiloxyleae and Heteropyxideae) (Wilson et al. 2005; Biffin et al. 2010). In Brazil, there are representatives of the current subfamily Myrtoideae.
Due to their morphological diversity, the colleters has been successfully used in taxonomic studies involving several botanical families (Woodson \& Moore 1938; Thomas 1991; Rio et al. 2002, 2005; Rio \& Kinoshita 2005; Simões et al. 2006; Silva et al. 2012). In addition, they have ecological importance because of their function of protection against dissection and pathogen attack (Lersten 1974; Mangalan et al. 1990; Miguel et al. 2009; Mayer et al. 2011; Rocha et al. 2011).

Considering that the colleters in Myrtoideae may help clarify the phylogenetic relationships of the Myrtaceae family (Silva et al. 2012) and the scarcity of descriptive studies about colleter of the Cerrado species (Mercadante-Simões \& Paiva 2013), the purpose of this study was to analyze the occurrence and morphological types of the colleters in six species belonging to three genera of Myrteae tribe belonging to Myrtoideae subfamily. These species were chosen because of their wide geographical distribution in Cerrado.

\section{Materials and Methods}

\section{Plant material}

Shoot meristems were collected from six species of three genera belonging to tribe Myrteae of Myrtoideae (sensu Wilson et al. 2005). Voucher material was deposited in the Herbarium (VIC) of the Universidade Federal de Viçosa (UFV) (Tab. 1).

\section{Light microscopy}

The collected material was selected under a stereoscopic microscope (Zeiss Stemi 2000-C Carl Zeiss, Germany), fixed in FAA (formalin: acetic acid: $70 \%$ ethanol (1:1:18 by volume) and stored in 70\% ethanol (Johansen 1940). Samples were dehydrated in ethanol series and embedded in methacrylate (Historesin, Leica Instruments, Heidelberg, Germany). Cross and longitudinal sections (4-6 $\mu \mathrm{m})$ were made using an automatic microtome (Zeiss - RM55) and stained with toluidine blue (O'Brien \& McCully 1981), $\mathrm{pH} 4.0$, for anatomical characterization. The slides were mounted in synthetic resin (Permount, Fisher Scientific, NJ, USA). The colleters classification was performed according to Silva et al. (2012).

\section{Histochemical analysis}

For histochemical tests on fresh material, branch sections with colleters were selected using a stereoscopic microscope and tested 
Table 1 - List of plant species studied.

\begin{tabular}{|c|c|c|c|c|}
\hline Species & Popular name & Georeferencing & $\begin{array}{l}\text { Collection } \\
\text { location }\end{array}$ & $\begin{array}{c}\text { Voucher } \\
\text { (VIC) }\end{array}$ \\
\hline Eugenia dysenterica DC. & Cagaita, cagaiteira & $19^{\circ} 28^{\prime} 30^{\prime \prime} \mathrm{S}, 44^{\circ} 11^{\prime} 50^{\prime \prime} \mathrm{W}$ & 1 & 48.717 \\
\hline Myrcia tomentosa (Aubl.) DC. & Goiaba brava & $21^{\circ} 15^{\prime} 50^{\prime \prime} \mathrm{S}, 44^{\circ} 41^{\prime} 10^{\prime \prime} \mathrm{W}$ & 2 & 48.718 \\
\hline Psidium cattleyanum Sabine & Araçá-amarelo & $21^{\circ} 16^{\prime} 26^{\prime} \mathrm{S}, 44^{\circ} 40^{\prime} 48^{\prime \prime} \mathrm{W}$ & 2 & 48.714 \\
\hline Psidium grandifolium Mart. ex DC. & Araçá catuba & 2115'16”S, 4441'22”'W & 2 & 48.722 \\
\hline Psidium guineense Sw. & Araçá-do-campo & $21^{\circ} 15^{\prime} 28^{\prime \prime S}, 44^{\circ} 41^{\prime} 14^{\prime \prime} \mathrm{W}$ & 2 & 48.713 \\
\hline Psidium laruotteanum Cambess. & Araçá-cascudo & $19^{\circ} 28^{\prime} 32^{\prime \prime} \mathrm{S}, 44^{\circ} 11^{\prime} 56^{\prime \prime} \mathrm{W}$ & 1 & 48.716 \\
\hline
\end{tabular}

${ }^{1}$ Campus Sete Lagoas of UFSJ; ${ }^{2}$ Rural property in Itutinga, MG.

with periodic acid-Schiff reagent (PAS) to detect general polysaccharides (McManus 1948), tannic acid-ferric chloride to detect mucilage (Pizzolato \& Lillie 1973), ruthenium red for acid mucilage (Gregory \& Baas 1989), Sudan IV to identify the lipophilic compounds (Pearse 1985), Wagner reagent for alkaloids (Furr \& Mahlberg 1981) and ferric chloride for phenolic compounds (Johansen 1940). In the Methacrylate-embedded material were applied the same tests and the Xylidine Ponceau (XP) for proteins (O'Brien \& McCully 1981). The controls were performed simultaneously, following recommendations in the literature. Material analysis and photographic documentation were performed using a light microscope (Primo Star, Carl Zeiss, Germany) equipped with a digital camera (model Axiocam ERc MRc 5s) and software Axiovision documentation (Carl Zeiss, Germany).

\section{Scanning electron microscopy}

The samples (leaf primordia and leaf buds bearing colleters) were fixed in a solution of $2.5 \%$ glutaraldehyde and $4 \%$ paraformaldehyde in 0.1 M phosphate-buffered saline, pH 7.3 (Karnovsky 1965), dehydrated in ethanol series and critical point-dried with $\mathrm{CO}_{2}$ in a Bal-Tec $020 \mathrm{CPD}$ dryer (Bal-Tec, Balzers, Liechtenstein). Samples were mounted on stubs and coated with gold by using an FDU 010 sputter coater (Bal-Tec). Examinations and photographs were carried out using a Leo 1430VP scanning electron microscope (Zeiss, Cambridge, UK) at the Microscopy and Microanalysis Center, UFV.

\section{Results}

Colleters were observed in the vegetative apices in all six species studied. Conic colleters were observed in Myrcia and Psidium genera and euryform colleters occurred in Eugenia genus (Figs. 1-3). Petaloid colleters were not found.

In all of the studied species, in the fresh and methacrylate-embedded material, the histochemical analysis revealed only the presence of hydrophilic compounds. The hydrophilic fraction of secretion stained with PAS (Figs. 1b,e; 2b,e,g), tannic acidferric chloride (Fig. 1f,h-i) and ruthenium red (Figs. 1c; 2m) indicating the presence of an acidic mucilage. No presence of lipophilic compounds, alkaloids and phenolic compounds was detected.

Colleters observed herein were translucent during the secretory phase turning to brown as they senesce (Fig. 1g).

In E. dysenterica the euryform colleters were higher than wide and some of them presented bifurcation in the apex (Fig. 3a). In longitudinal section, it was observed that they have a narrow base (Fig. 2a). Conic colleters in P. cattleyanum occurred in a row between the leaf primordia surrounding the buds (Fig. 2k-1). They presented tapered apex and increases diameter towards the base. In $P$. grandifolium, $P$. guineense and $M$. tomentosa the conic colleters were found between several trichomes (Figs. 2g,i; 3b-c,g). The colleters in P. grandifolium presented a broad base (Fig. 2c).

In all species, the colleters were nonvascularized and showed simple and homogeneous cellular compositions, with no secretory epithelium. 


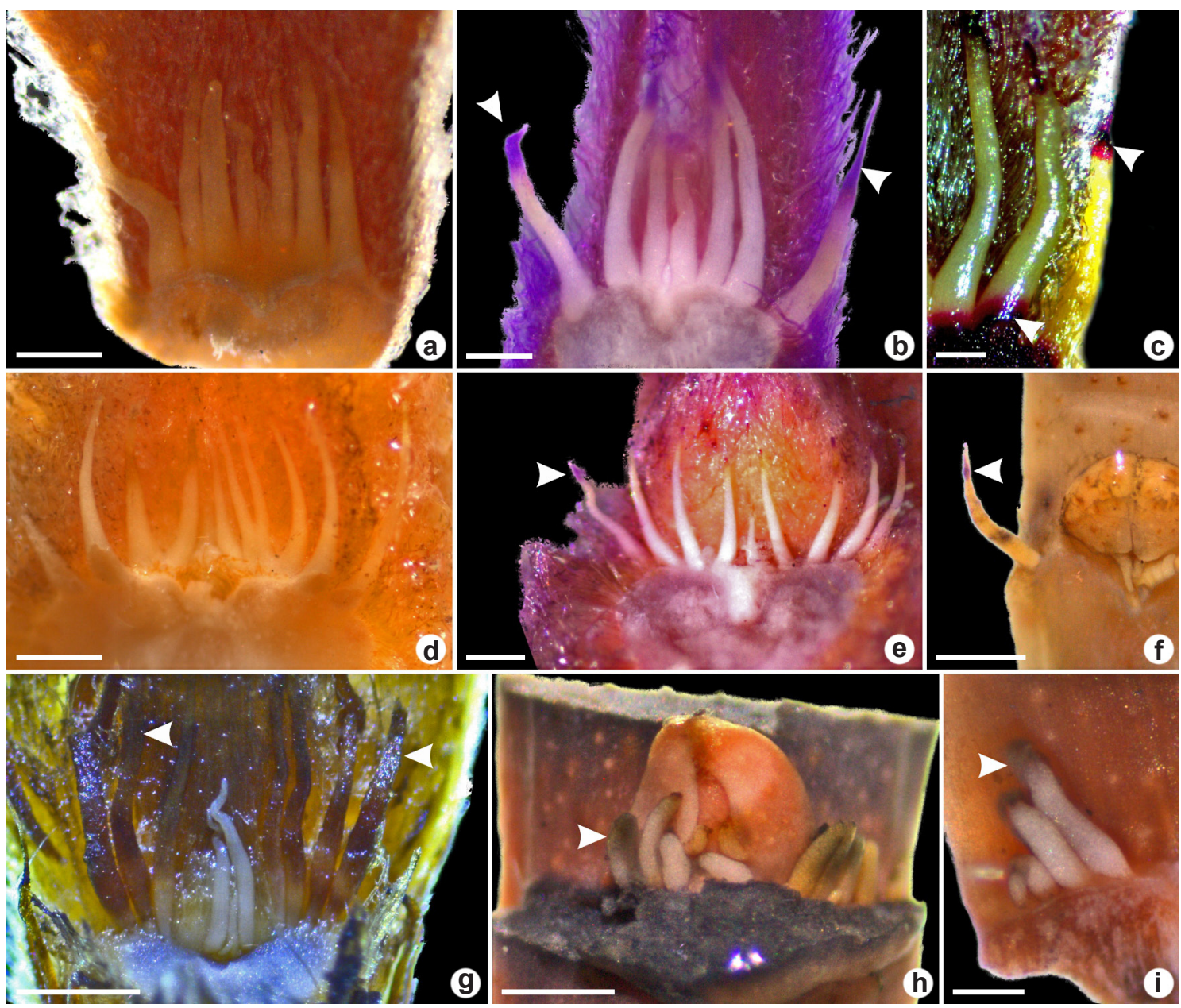

Figure 1 - a-i. Colleters in vegetative apices of Myrtoideae species viewed under a stereomicroscope - a-c. conic colleters in Psidium grandifolium; d-e. conic colleters in P. guineense; f. conic colleters in P. cattleyanum; g. conic colleters in Myrcia tomentosa (arrowheads indicate the senescent colleter); h-i. euryphorm colleters in Eugenia dysenterica. (a,d,g. fresh samples; b,e. sample treated with periodic acid-Schiff's reagent indicating polysaccharides; f,h-i. samples treated with tannic acid-ferric chloride, indicating mucilage; c. positive ruthenium red reaction. Scale bars: a,e,i: $0.4 \mathrm{~mm}$; b,c,h: $0.2 \mathrm{~mm}$; d: $0.5 \mathrm{~mm}$; f,g: $0.8 \mathrm{~mm}$ ).

In longitudinal section, the parenchymatic cells were elongated, with cytoplasm similar to epidermal cells. They presented thin walls, dense cytoplasm and nucleus in medial or basal position.

The scanning electron microscopy revealed the secretion accumulation in the apical and medial region of the colleters (Fig. 3a,d-f). It was not detected pores or cracks in the cuticle, either by light or scanning electron microscopy which indicates the mechanisms of secretion release.

\section{Discussion}

Euryform colleters observed herein in $E$. dysenterica was reported in E. brasiliensis Lam.,
E. floribunda (H. West ex Willd.) O. Berg, E. involucrata DC. and E. uniflora L. (Silva et al. 2012). However, conic colleters were also reported in Eugenia (Silva et al. 2012), which confirms that more than one colleter type may occur in the same genus (Silva et al. 2012).

Although the conic colleters have been reported in Myrcia and Psidium genera (Silva et al. 2012), there is no record of this broad-based structure as it was observed in $P$. guineense and $P$. grandifolium.

Euryform colleters seem to be common in the Eugenia genus as well as conic colleters in Myrcia and Psidium genera, both of them from 

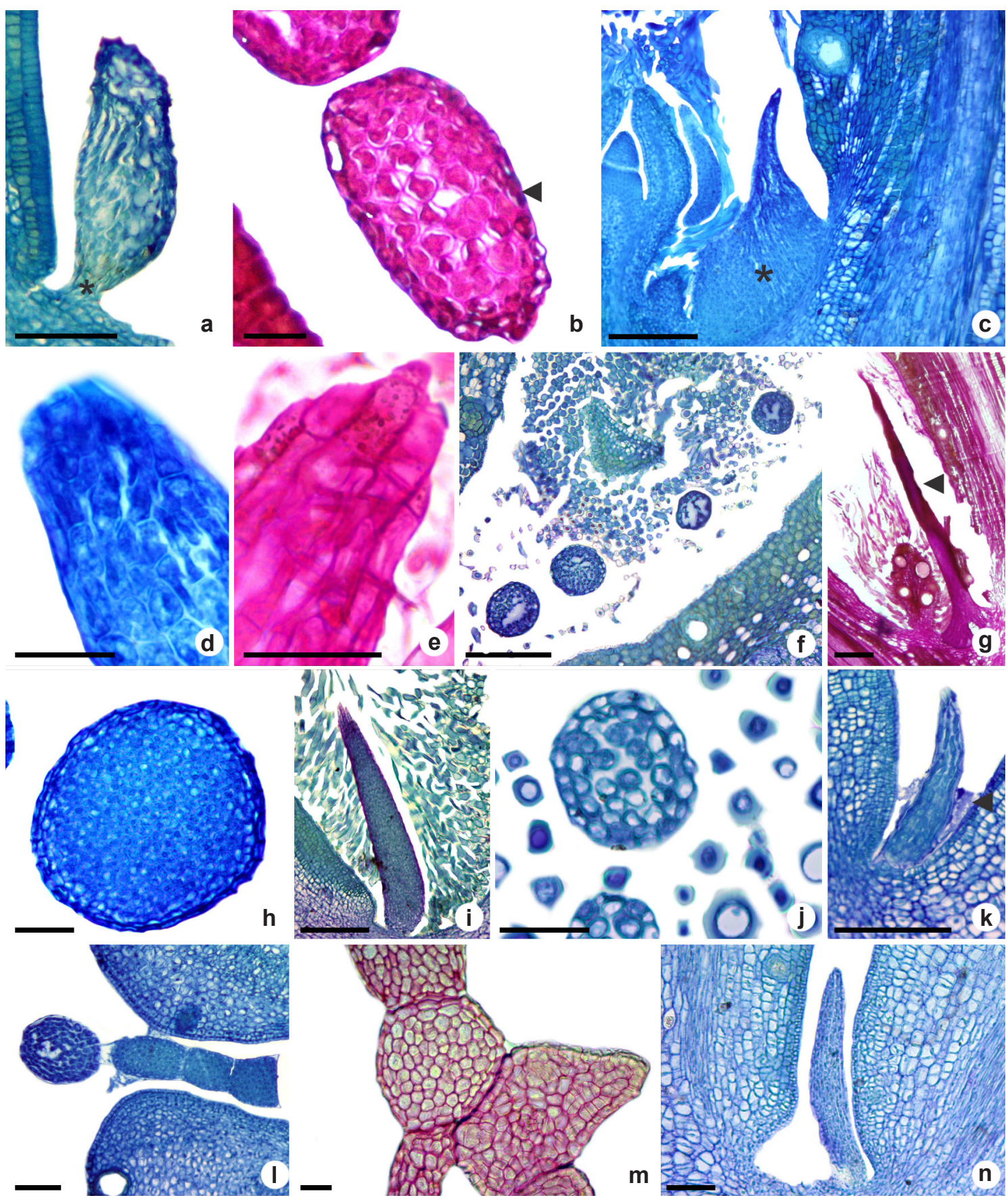

Figure 2 - a-n. Anatomical structure of colleters of Myrtoideae species in longitudinal sections (a,c,d-e,g,i,k-1,n) and cross-sections (b,f,h, , , , m $)$ - a-b. euryform colleter Eugenia dysenterica; c-g. conic colleters in Psidium grandifolium; h-i. conic colleters in P. guineense; j. conic colleters in Myrcia tomentosa; k-l. conic colleters in P. cattleyanum; $\mathrm{m}-\mathrm{n}$. conic colleters in P. laruotteanum. (a,c-d,f,h-l,n. toluidine-blue staining; b,e,g. positive periodic acid-Schiff's reaction, indicating polysaccharides in the secretion [arrowhead]; $\mathrm{m}$. positive ruthenium red reaction). (* = broad base; scale bars: a,h $=80 \mu \mathrm{m} ; \mathrm{b}=20 \mu \mathrm{m} ; \mathrm{c}, \mathrm{f}-\mathrm{g}, \mathrm{i}, \mathrm{k}=200 \mu \mathrm{m} ; \mathrm{d}-\mathrm{e}, \mathrm{j}, \mathrm{m}=40 \mu \mathrm{m} ; 1, \mathrm{n}=100 \mu \mathrm{m}$ ). 

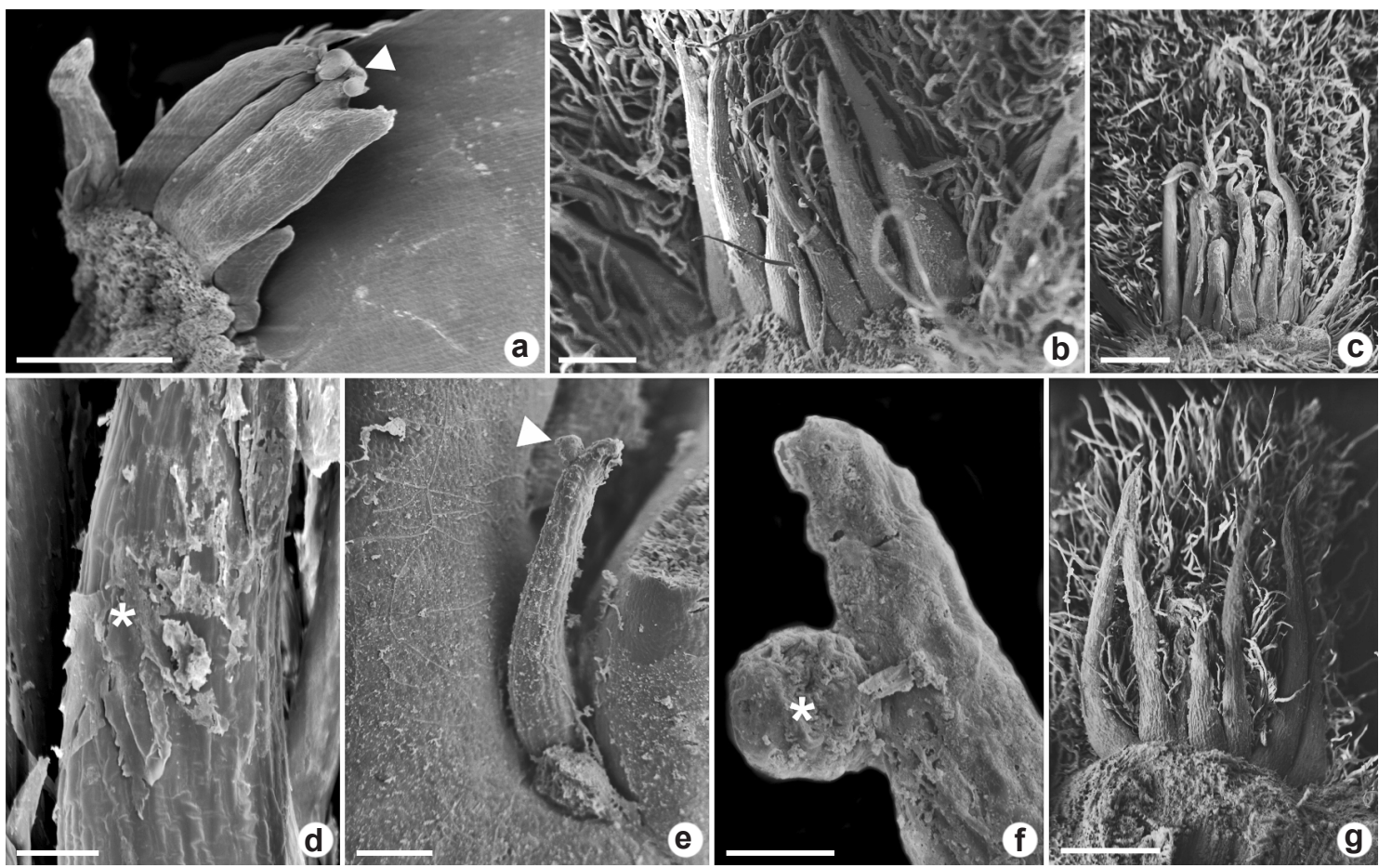

Figure 3 - a-g. Colleters in vegetative apices of Myrtoideae species viewed under a scanning electron microscope - a. euryform colleter in Eugenia dysenterica with the bifurcate apex; b-d. conic colleters in Psidium guineense; e-f. conic colleters in P. cattleyanum; g. conic colleters in $P$. grandifolium. (arrowheads and $*=$ secretion accumulation; scale bars: $\mathrm{a}-\mathrm{b}=200 \mu \mathrm{m} ; \mathrm{c}-\mathrm{d}, \mathrm{g}=400 \mu \mathrm{m}$; $\mathrm{e}=100 \mu \mathrm{m} ; \mathrm{f}=20 \mu \mathrm{m})$.

the Myrteae Tribe, although they are not restricted to these tribes. The colleters morphological type in the Myrtoideae tribes seems to be variable and according to Silva et al. (2012) may support the hypothesis proposed by Biffin et al. (2010) that the multiple fleshy-fruit lineages have evolved independently in Myrteae Tribe. Conic colleter have been reported in 19 species belonging to three tribes (Leptospermeae, Melaleucae and Myrteae), the petaloid colleter in 10 species from three Tribes (Lophostemoneae, Melaleucae and Sizygeae), the euryform colleter in 12 species from five tribes (Leptospermae, Melaleucae, Myrteae Syncarpieae and Syzygieae) and in the Eucalypteae tribe was reported the nonoccurrence of colleter (Silva et al. 2012).

The absence of petaloid colleters observed herein was also reported for Syzygium jambos and Callistemon viminalis (Silva et al. 2012) and seems to be related to the morphological organization of the structures that surrounds and protects the apical meristems. When the apical meristems are completely covered by imbricated cataphylls, it was observed petaloid colleter occurrence between them. But in the absence of this arrangement, the conic and euryform colleters occurred in the axils of the foliar primordia or young leaves that cover the buds on young branches (Silva et al. 2012), as noted in the species in this work.

The non-vascularisation in the Myrtoideae colleters has already been described (Silva et al. 2012). The transport of secretory precursors may occur by the symplastic pathway, through the plasmodesmata as discussed by Souza (2014). The same process was reported in species of the families Apocynaceae (Appezzato-da-Glória \& Estelita 2000; Souza 2014), Caryocaraceae (Paiva \& Machado 2006) and Rubiaceae (Vitarelli \& Santos 2009).

The mucilaginous nature of colleter secretion in Myrtoideae, confirmed by histochemical tests, is known in the literature for this secretory structure (Lersten \& Horner 1968; Lersten 1974; Fahn 1979; Vitarelli \& Santos 2009; Silva et al. 2012). Its ecological function is to lubricate and protect buds in the initial phase of the development, especially against desiccation (Fahn 1979; Foster 1942; Paiva \& Machado 2006; Barreiro \& Machado 2007; 
Sheue et al. 2012; Mayer et al. 2013; Coutinho et al. 2016). This function is essential for Cerrado species, which are exposed to excessive solar radiation and constant winds and can be understood as a factor that contributes to adaptation to this biome.

The non-occurrence of proteins in the secretions exuded by the colleters seems to be common for species of the subfamily Myrtoideae and has been previously reported (Silva et al. 2012). The presence of proteins in the colleter secretions was observed in families such as Apocynaceae (Leite 2012), Rubiaceae (Castro et al. 2006), Caryocaraceae (Paiva \& Machado 2006) e Malvaceae (Rocha et al. 2011), and are understood as a defense mechanism against pathogens and herbivores (Klein et al. 2004; Demarco 2005; Leite 2012).

The mechanisms of secretion liberation seem to be by cuticle permeability as suggested by Silva et al. (2012), since the secretion accumulates in the apex and medial region of the colleter, however without evidence of pores or cracks for its release.

The conic and euryform colleters from Myrtoideae species of the Cerrado did not differ either morphologically nor as to the secretion nature from those described by Silva et al. (2012) for Myrtoideae species from others biomes, which may indicate their potential use for taxonomic purposes. Considering the hypothesis that the multiple fleshy-fruit lineages have evolved independently in Myrteae tribe (Biffin et al. 2010), our results indicate the relevance of additional studies in order to recognize the pattern of distribution of colleters in Myrtaceae.

\section{References}

APG III (2009) An update of the Angiosperm Phylogeny Group classification for theorders and families of flowering plants: APG III. Botanical Journal of the Linnean Society 161: 105-121.

Appezzato-da-Glória B \& Estelita MEM (2000) The developmental anatomy of the subterranean system in Mandevilla illustris (Vell.) Woodson and M. velutina (Mart. ex Stadelm.) Woodson (Apocynaceae). Revista Brasileira de Botânica 23: 7-35.

Barreiro DP \& Machado SR (2007) Coléteres dendróides em Alibertia sessilis (Vell.) K. Schum., uma espécie não-nodulada de Rubiaceae. Revista Brasileira de Botânica 30: 387-399.

Barros TC \& Teixeira SP (2016) Revisited anatomy of anther glands in mimosoids (Leguminosae). International Journal of Plant Sciences 177: 18-33.
Biffin E, Lucas EJ, Craven LA, da-Costa IR, Harrington MG \& Crisp MD (2010) Evolution of exceptional species richness among lineages of fleshy-fruited Myrtaceae. Annals of Botany 106: 79-93.

Cardoso-Gustavson P, Campbell LM, MazzoniViveiros SC \& Barros F (2014) Floral colleters in Pleurothallidinae (Epidendroideae: Orchidaceae). American Journal of Botany 101: 587-597.

Castro ME, Oliveira MA, Cunha M \& Moreira Gomes V (2006) Colleters in Bathysa nicholsonii K. Schum. (Rubiaceae): ultrastructure, secretion protein composition, and antifungal activity. Plant Biology (Stuttgart) 8: 715-722.

Coutinho IAC, Rando JG, Conceição AS \& Meira RMSA (2016) A study of the morphoanatomical characters of the leaves of Chamaecrista (L.) Moench sect. Apoucouita (Leguminosae-Caesalpinioideae). Acta Botanica Brasilica 30: 205-221.

Demarco D (2005) Estruturas secretoras florais e coléteres foliares em espécies de Cerrado de Aspidosperma Mart. e Blepharodon Decne. (Apocynaceae). Dissertação de Mestrado. Universidade Estadual de Campinas, Campinas. 226p.

Fahn A (1979) Secretory tissues in plants. Academic Press, London. 302p.

Foster AS (1942) Practical plant anatomy. D. van Nostrand Company, Inc., New York. 172p.

Furr M \& Mahlberg PG (1981) Histochemical analyses of laticifers and glandular trichomes in Cannabis sativa. Journal of Natural Products 44: 153-159.

González AM \& Tarragó JR (2009) Anatomical structure and secretion com-pounds of colleters in nine Ilex species (Aquifoliaceae) from southern South America. Botanical Journal of the Linnean Society 160: 197-210.

Gregory M \& Baas P (1989) A survey of mucilage cells in vegetative organs of the dicotyledons. Israel Journal of Plant Sciences 38: 125-174.

Johansen DA (1940) Plant microtechnique. McGraw Hill: London. 487p.

Johnson LAS \& Briggs BG (1984) Myrtales and Myrtaceae - a phylogenetic analysis. Annals of the Missouri Botanical Garden 71: 700-756.

Karnovsky MJ (1965) A formaldehyde-glutaraldehyde fixative of high osmolality for use in electron microscopy. Journal of Cellular Biology 27: 137138.

Klein DE, Gomes VM, Silva-Neto SJ \& Da Cunha M (2004) The structure of colleters in several species of Simira (Rubiaceae). Annals of Botany 94: 733-740.

Lacchia APS, Tölke EEAD, Carmello-Guerreiro SM, Ascensão L \& Demarco D (2016) Foliar colleters in Anacardiaceae: first report for the family. Botany 94: 337-346.

Leitão CAE \& Cortelazzo AL (2008) Structural and histochemical characterization of the colleters of Rodriguezia venusta (Orchidaceae). Australian Journal of Botany 56: 161-165. 
Leite RG (2012) Anatomia de coléteres e natureza química das secreções em quatro espécies de plantas nativas do Cerrado e seu papel ecológico em Himatanthus obovatus (Apocynaceae). Tese de Doutorado. Universidade de Brasília, Brasília. $106 \mathrm{p}$.

Lersten NR \& Horner HTJr (1968) Development, structure and function of secretory trichomes in Psychotria bacteriofila (Rubiaceae). American Journal of Botany 55: 1089-1099.

Lersten NR (1974) Morphology and distribution of Colleters and crystals in relation to the taxonomy and bacterial leaf nodule symbiosis of Psychotria (Rubiaceae). American Journal of Botany 61: 973-981.

Lopes-Mattos KLB, Otuki SAP, Azevedo AA, Pereira ZV \& Meira RMSA (2015) Colleters in 10 species belonging to three tribes of Rubiaceae: morphoanatomical diversity and potential as useful characters for taxonomy. Botany 93: 425-434.

Macêdo TP, Cortez PA \& Costa LCB (2016) First record of colleters in Zanthoxylum Linn. species (Rutaceae Juss., Sapindales): structural, functional and taxonomic considerations. Flora 224: 66-74.

Machado AFP, Souza AM \& Leitão CAE (2013) Secretory structures at syconia and flowers of Ficus enormis (Moraceae): a specialization at ostiolar bracts and the first report of inflorescence colleters. Flora 208: 45-51.

Machado SR, Paleari LM, Paiva EAS \& Rodrigues TM (2015) Colleters on the inflorescence axis of Croton glandulosus (Euphorbiaceae): structural and functional characterization. International Journal of Plant Sciences 176: 86-93.

Mangalan S, Kurien KP, John P \& Nair GM (1990) Development, structure and cytochemistry of resin secreting colleters of Gardenia gummifera (Rubiaceae). Annals of Botany 66: 123-132.

Mayer JLS, Cardoso-Gustavson P \& Appezzato-daGlória B (2011) Colleters in monocots: new record for Orchidaceae. Flora 206: 185-190.

Mayer JLS, Carmello-Guerreiro SM \& Mazzafera P (2013) A functional role for the colleters of coffee flowers. AoB Plants 5: 1-13.

McManus JFA (1948) Histological and histochemical uses of periodic acid. Stain Technology 23: 99-108.

Mendonça RC, Felfili JM, Walter BMT, Silva Junior MC, Rezende AV, Filgueiras TS \& Nogueira PE (1998) Flora vascular do Cerrado. In: Sano SM \& Almeida SP (ed.) Cerrado: ambiente e flora. Vol. 2. Embrapa Cerrados, Planaltina. Pp. 289-556.

Mercadante-Simões MO \& Paiva EAS (2013) Leaf colleters in Tontelea micrantha (Celastraceae, Salacioideae): Ecological, morphological and structural aspects. Comptes Rendus Biologies 336: 400-406.

Miguel EC, Moraes DG \& Da Cunha M (2009) Stipular colleters in Psychotria nuda (Cham \& Schltdl.)
Wawra (Rubiaceae): micromorphology, anatomy and crystalsmicroanalysis. Acta Botanica Brasilica 23: 1034-1039.

Moura GS \& Franzener G (2015) Anatomia foliar de Corymbia citriodora (hook.) KD Hill \& LAS Johnson oriundas da região noroeste do Paraná. Revista de Biologia Neotropical 11: 116-123.

Muravnik LE, Kostina OV \& Shavarda AL (2014) Development, structure and secretion compounds of stipule colleters in Pentas lanceolata (Rubiaceae). South African Journal of Botany 93: $27-36$

O‘brien TP \& McCully ME (1981) The study of plant structure principles and select methods. Termarcarphi Pty, Melbourne. 345p.

Oliveira CS, Salino A \& Paiva EAS (2017) Colleters in Thelypteridaceae: unveiling mucilage secretion and its probable role in ferns. Flora 228: 65-70.

Paiva EAS \& Machado SR (2006) Colleters in Caryocar brasiliense (Caryocaraceae) ontogenesis, ultrastructure and secretion. Brazilian Journal of Biology 66: 301-308.

Paiva EAS (2012) Colleters in Cariniana estrellensis (Lecythidaceae): structure, secretion and evidences for young leaf protection. The Journal of the Torrey Botanical Society 139: 1-8.

Pearse AGE (1985) Histochemistry theoretical and applied. Vol. 2. Churchill Livingstone, Edinburgh. $613 \mathrm{p}$.

Pizzolato TD \& Lillie RD (1973) Mayer's tannic acid-ferric chloride stain for mucins. The Journal of Histochemistry and Cytochemistry 21: 56-64.

Renobales G, De Diego E, Urcelay B \& LópezQuintana A (2001) Secretory hairs in Gentiana and allied genera (Gentianaceae: subtribe Gentianinae) from the Iberian Peninsula. Botanical Journal of the Linnean Society 136: 119-129.

Rio MCS \& Kinoshita LS (2005) Prestonia (Apocynaceae) no Sul e Sudeste do Brasil. Hoehnea 32: 233-258.

Rio MCS, Kinoshita LS \& Castro MM (2005) Anatomia foliar como subsídio para a taxonomia de espécies de Forsteronia G. Mey. (Apocynaceae) dos Cerrados paulistas. Revista Brasileira de Botânica 28: 713-726.

Rio MS, Castro MM \& Kinoshita LS (2002) Distribuição e caracterização anatômica dos coléteres foliares de Prestonia coalita (Vell.) Woodson (Apocynaceae). Revista Brasileira de Botânica 25: 339-349.

Rocha JF, Pimentel RR \& Machado SR (2011) Estruturas secretoras de mucilagem em Hibiscus pernambucensis Arruda (Malvaceae): distribuição, caracterização morfoanatômica e histoquímica. Acta Botânica Brasílica 25: 751-763.

Sano SM, Almeida SP \& Ribeiro JF (2008) Cerrado: ecologia e flora. Embrapa Informação Tecnológica, Brasília. 1279p. 
Sheue C-R, Chen Y-J \& Yang Y-P (2012) Stipules and colleters of the mangrove Rhizophoraceae: morphology, structure and comparative significance. Botanical Studies 53: 243-254.

Silva CJ, Barbosa LCDA, Marques AE, BaracatPereira MC, Pinheiro AL \& Meira RM (2012) Anatomical characterisation of the foliar colleters in Myrtoideae (Myrtaceae). Australian Journal of Botany 60: 707-717.

Simões AO, Castro MM \& Kinoshita LS (2006) Calycine colleters of seven species of Apocynaceae (Apocynoideae) from Brazil. Botanical Journal of the Linnean Society 152: 387-398.

Souza LA (2014) Estruturas secretoras em espécies de leguminosas da subtribo Cassiinae (Fabaceae, Caesalpinioideae, Cassieae). Tese de Doutorado. Universidade Federal de Minas Gerais, Belo Horizonte. $101 \mathrm{p}$.

Thomas V (1991) Structural, functional and phylogenetic aspects of the colleter. Annals of Botany 68: 287-305.

Tresmondi F, Nogueira A, Guimarães E \& Machado SR (2015) Morphology, secretion composition, and ecological aspects of stipular colleters in Rubiaceae species from tropical forest and savanna. The Science of Nature 102: 73.

Vitarelli NC \& Santos M (2009) Anatomia de estípulas e coléteres de Psychotria carthagenensis Jacq. (Rubiaceae). Acta Botanica Brasilica 23: 923-928.

Vitarelli NC, Riina R, Caruzo MBR, Cordeiro I, Fuertes-Aguilar J \& Meira RMSA (2015) Foliar secretory structures in Crotoneae (Euphorbiaceae): diversity, anatomy, and evolutionary significance. American Journal of Botany 102: 833-847.

Wilson GW, O`Brien MM, Gadek PA \& Quinn CJ (2001) Myrtaceae revisited: a reassessment of intrafamiliar groups. American Journal of Botany 88: 2013- 2025.

Wilson PG, O’Brien MM, Heslewood MM \& Quinn CJ (2005) Relationships within Myrtaceae sensu lato based on a matK phylogeny. Plant Systematics and Evolution 251: 3-19.

Woodson JRE \& Moore JA (1938) The vascular anatomy and comparative morphology of apocynaceous flowers. Bulletim of the Torrey Botanical Club 65: $135-169$. 